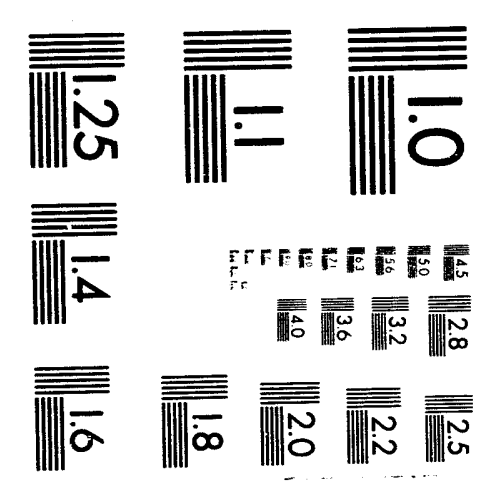



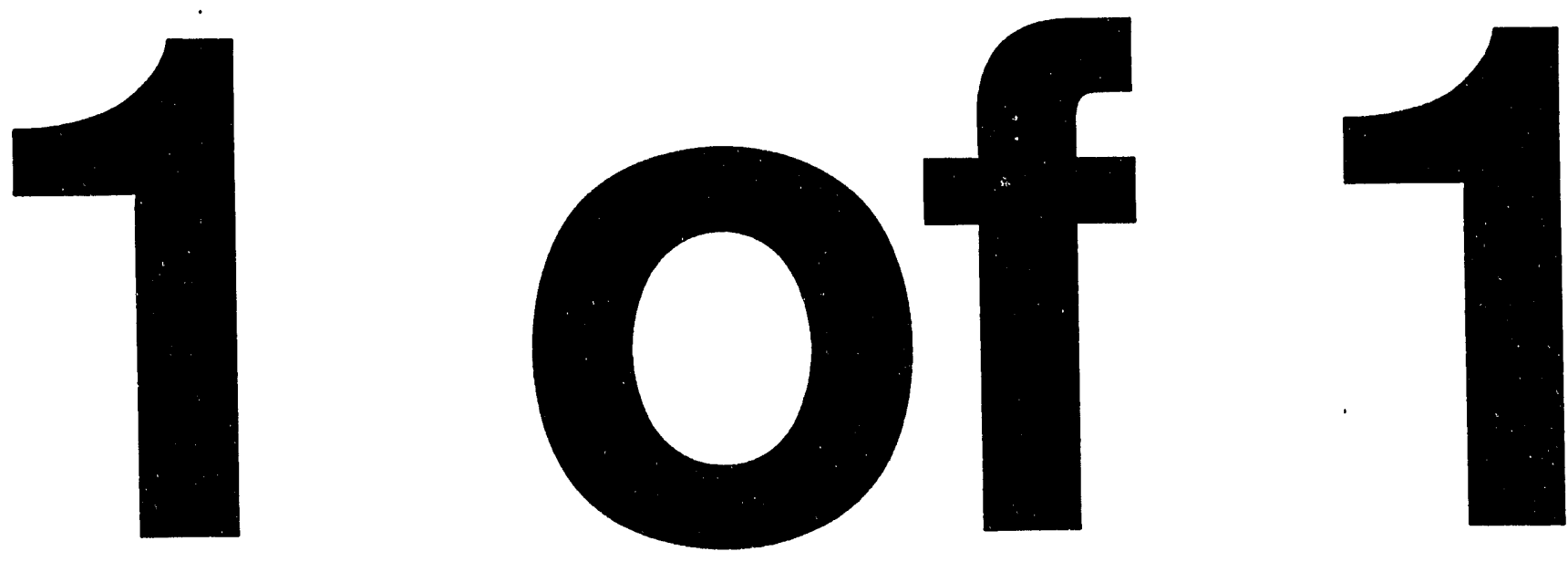
Paper prepared for EURADOS Working Group 10 ADVANCES IN RADIATION MEASUREMENTS

\title{
MICRODOSIMETRY OF MONOENERGETIC
} NEUTRONS 1

\author{
Dušan Srdoč ${ }^{2}$ \\ Brookhaven National Laboratory, Upton, N.Y. 11973 \\ and \\ Stephen A. Marino
}

Center for Radiological Research, Department of Radiation Oncology, Columbia University, College of Physicians and Surgeons

New York, N.Y. 10032

${ }^{1}$ This investigation was supported by grant CA 12536 to the Radiological Research Laboratory/Department of Radiology, and grant CA 13696 to the Cancer Center/Institute of Cancer Research awarded by the NCI, DHEW, and by contract DE-ACO2-78EVO4733 from the Department of Energy.

2 The author acknowledges support by NSF, Research Project JF-802, and by the International Atomic Energy Agency, Research Project 5293.

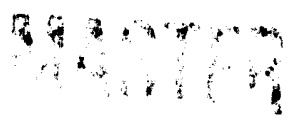




\title{
MICRODOSIMETRY OF MONOENERGETIC NEUTRONS ${ }^{1}$
}

\author{
Dušan Srdoč 2 \\ Brookhaven National Laboratory, Upton, N.Y. 11973 \\ and \\ Stephen A. Marino \\ Center for Radiological Research, Department of Radiation Oncology, \\ Columbia University, College of Physicians and Surgeons \\ New York, N.Y. 10032
}

\section{ABSTRACT}

Tissue spheres $0.25,0.5,1.0,2.0,4.0$, and $8.0 \mu \mathrm{m}$ in diameter were simulated using a wall-less spherical counter Eilled with a propane-based tissue-equivalent gas. Microdosimetric spectra corresponding to these site sizes were measured for five neutron energies $(0.22,0.44,1.5,6$, and $14 \mathrm{MeV})$ and the related mean values $\bar{Y}_{F}$ and $\bar{Y}_{D}$ were calculated for several site sizes and neutron energies. An elaborate calibration technique combining soft $x$-rays, a $55 \mathrm{Fe}$ photon source, and a $244 \mathrm{~cm}$ collimated source of alpha particles was used throughout the measurement. The spectra and their mean values are compared with theoretically calculated values for ICRU tissue. The agreement between the calculated and the measured data is good in spite of a systematic discrepancy, which could be attributed, in part, to the difference in elemental composition between the tissue-equivalent gas and plastic used in the counter, and the ICRU standard tissue used in the calculations.

1 This investigation was supported by grant CA 12536 to the Radiological Research Laboratory/Department of Radiology, and grant CA 13696 to the Cancer Center/Institute of Cancer Research awarded by the NCI, DHEW, and by contract DE-ACO2-78EVO4733 from the Department of Energy.

2 The author acknowledges support by NSF, Research Project JF802, and by the International Atomic Energy Agency, Research Project 5293 .

\section{DISCLAIMER}

This report was prepared as an account of work sponsored by an agency of the United States Government. Neither the United States Government nor any agency thureof, nor any of their employees, makes any warranty, express or implied, or assumes any legal liability or responsibility for the accuracy, completeness, or usefulness of any information, apparatus, product, or process disclosed, or represents that its use would not infringe privately owned rights. Reference herein to any specific commercial product, process, or service by trade name, trademark, manufacturer, or otherwise does not necessarily constitute or imply its endorsement, recommendation, or favoring by the United States Government or any agency thereof. The views and opinions of authors expressed herein do not necessarily state or reflect those of the Inited Stateres Government: or any aoency thereof. 


\section{INTRODUCTION}

The distribution patterns of energy deposition in small tissue spheres $(d=0.1-10 \mu \mathrm{m})$ irradiated by neutron beams have been the subject of extensive experimental and theoretical studies (1-20). Earlier experimental work was primarily motivated by the unique advantages of neutrons as a tool for understanding basic mechanisms in radiobiology (21). The advent of neutron radiotherapy has stimulated further microdosimetric measurements needed to specify beam quality in treatment fields $(22,23)$. The experimental measurements have beer accompanied by theoretical calculations aimed at a better understanding of the interaction of neutrons with tissue, and the subsequent ionization and excitation processes (24). Microdosimetric measurements of neutron radiation are equally important in radiation protection studies, helping to evaluate the radiation quality factor (25, $26,27,28$ ).

The energy deposition patterns in simulated small tissue volumes inzadiated by neutrons have sesn measured (1-9) and calculated (10-20) Much of the early experimental microdosimetric data for monoenergetic neutrons were obtained by the Radiologicai Research Laboracory (RRL; OE Columbia University and published in their Annual Reports. There are two distinct groups of data: the first group published in 1967 by Biavati and Boer (1), and covering work from 1964 to 1967, and the later one, published by Rodgers et al., in 1973 (3). Rodgers and Gross summarized the lateer report at the Eourth Microdosimetry symposium (1974), 
pointing out, however, that the data were preliminary (6). The disagreement between these two groups of data ranges from 10 to $33 \%$ and prompted us to undertake the comprehensive, systematic measurements presented in this paper. Before 1970, measurements were made with electronics and processing devices that are obsolete by modern standards, and further, the counter calibration was imprecise; some published papers $(3,6)$ reported only preliminary data that was never confirmed. This situation justified our effort to undertake systematic measurements of energy deposition spectra for a wide range of simulated site sizes and neutron energies. Progress reports describing an early stage of the work done at Radiological Research Accelerator Facility have been published $(29,30)$ and some preliminary results have been presented at Seventh Symposium on Microdosimetry (7).

Several factors which may influence the results, such as the counter size and the thickness of its wall were investigated in some detail. Substantial improvements in the design of the spherical counter. in calibration techniques, and in electronics, briefly described in the Eollowing section, enabled us to measure the spectra with a high degree of reproducibility.

Microdosimetric spectra are presented in the usual notation of $d(y)$ vs $\log (y)$ or $y d(y)$ vs $\log (y)(31,32)$, and the contributions of gamma rays, protons, alpha particles, and heavy recoils are discussed briefly. 


\section{EXPERIMENTAL}

\subsection{The wall-less counter and electronics}

A miniature version of the Rossi-type, tissue-equivalent (TE), spherical wall-less counter, described in detail in (3) and (33), was used for our experiments. The counter consists of a $6.35 \mathrm{~mm}$ spherical grid, a helix, and the central anode, all contained in a TE plastic sphere, $2.54 \mathrm{~cm}$ in diameter. The thickness of the wall of the TE plastic sphere must exceed a critical vaiue which depends on the tyoe and energy of the incident radiat:on to obtain the secondary particle equilibrium. The small size of the counter enabled us to measure very small simuiared site sizes $(0.25-0.5 \mu \mathrm{m})$.

A low noise FET preamplifier, developed by Radeka (34), extended the measurements down to energy depositions consisting of several ion pairs per event. In addition, a specially designed amplifier with logarithmic response (35) was used to accommodate the extremely broad range of pulse height. The low-noise preamplifier was connected directiy to the anode of the proportional counter. Analog pulses from tine preamplifier were fed through a logarithmic amplifier into an analogto-digital converter and stored in the nemory of a PDP-8 computer. Data analysis was performed both on- and off-line with specially developed software. 


\subsection{The neutron source}

Monoenergetic neutrons having mean energies of $0.22,0.44,1.5$, 6.0, and $14 \mathrm{MeV}$ were used to irradiate TE wall-less counters with diameters equivalent to $0.25,0.5,1.0,2.0,4.0$, and $8.0 \mu \mathrm{m}$ of tissue. The conditions during irradiation were similar to those often used in radiobiological experiments, so that the microdosimetric parameters car be used for biophysical calculations. Data on the neutron source and counter irradiation geometry are shown in Table 1 .

TABLE 1. NEUTRON SOURCE DATA AND COUNTER IRRADIATION GEOMETRY

\begin{tabular}{|c|c|c|c|c|c|}
\hline $\begin{array}{l}\text { Mean } \\
\text { erdergy }\end{array}$ & $\begin{array}{l}\text { heutron } \\
\text { (MeV) }\end{array}$ & Reaction & $\begin{array}{l}\text { Approx } \\
y \text {-ray } \\
\text { dose }(\%)\end{array}$ & $\begin{array}{l}\text { Counter } \\
\text { Distance =0 } \\
\text { target }(\mathrm{cm})\end{array}$ & $\begin{array}{l}\text { position } \\
\text { Angle Exom } \\
\text { ion beam (deg) }\end{array}$ \\
\hline 0.22 & $\pm 44 \%$ & $T(p, n)$ & 1 & 11.5 & 100 \\
\hline 0.44 & $\pm 10 \%$ & $T(p, n)$ & 1.5 & 11.5 & 120 \\
\hline 1.5 & $\pm \quad 9 \%$ & $T(p, n)$ & 1 & 10.4 & D \\
\hline 6 & $\pm 8 \%$ & $D(a, n)$ & 6 & 11.5 & J \\
\hline 14 & $\pm \quad 7 \%$ & $T(d, n)$ & 4 & 12.0 & 100 \\
\hline
\end{tabular}


Neutrons were produced using proton or deuteron beams from the Radiological Research Accelerator Facility 4-MV Van de Graaff then at Brookhaven National Laboratory. The charged particie beams were incident on targets consisting of a copper backing with a thin titanium layer in which either tritium or deuterium was absorbed. The target, target holder, and water cooling lines were designed to minimize attenuation and scatter.

\subsection{The microdosimetric measurement technique}

The experimental technique generally followed that described by Srdoc (33). Two spherical, wall-less Rossi-type counters were used throughout the measurements. The "I-inch" counter, used in previous experiments by Rodgers and Gross (6) was described by them in detail (3). The "1/4-inch" counter has essentially the same design, but scaled down by a factor of 4. However, this smaller counter has two distinct Eeatures: a) it is enclosed in a thin Al shell, and b) it has an inner layer, made of TE plastic, which can be changed or removed. In adition, the smailer physicai size of this decector improves ics operational stability, especially when small tissue site sizes are simulated, because of the higher gas pressure for a given site size relative to the 1 -inch counter. Spectra obtained from both counters were compared for a range of neutron energies and simulated site sizes, and no significant differences were observed. 
There were no changes in spectral shapes when a $3 \mathrm{~mm}$-thick outside layer of TE plastic was placed on the Al shell; therefore, subsequent measurements were made without it. The thickness of the inner layer of TE-plastic is very critical at high neutron energies. For instance, a $0.25 \mathrm{~mm}$ thick TE plastic wall is insufficient to maintain secondary particle equilibrium, resulting in a distorted spectrum of íMeV neutrons as shown in Fig. 1, curve 1, in contrast to a $3-\mathrm{mm}$ thich layer, which produces equilibrium (curve 2). Further increases in the thickness of the plastic do not influence the spectrum. The counter was
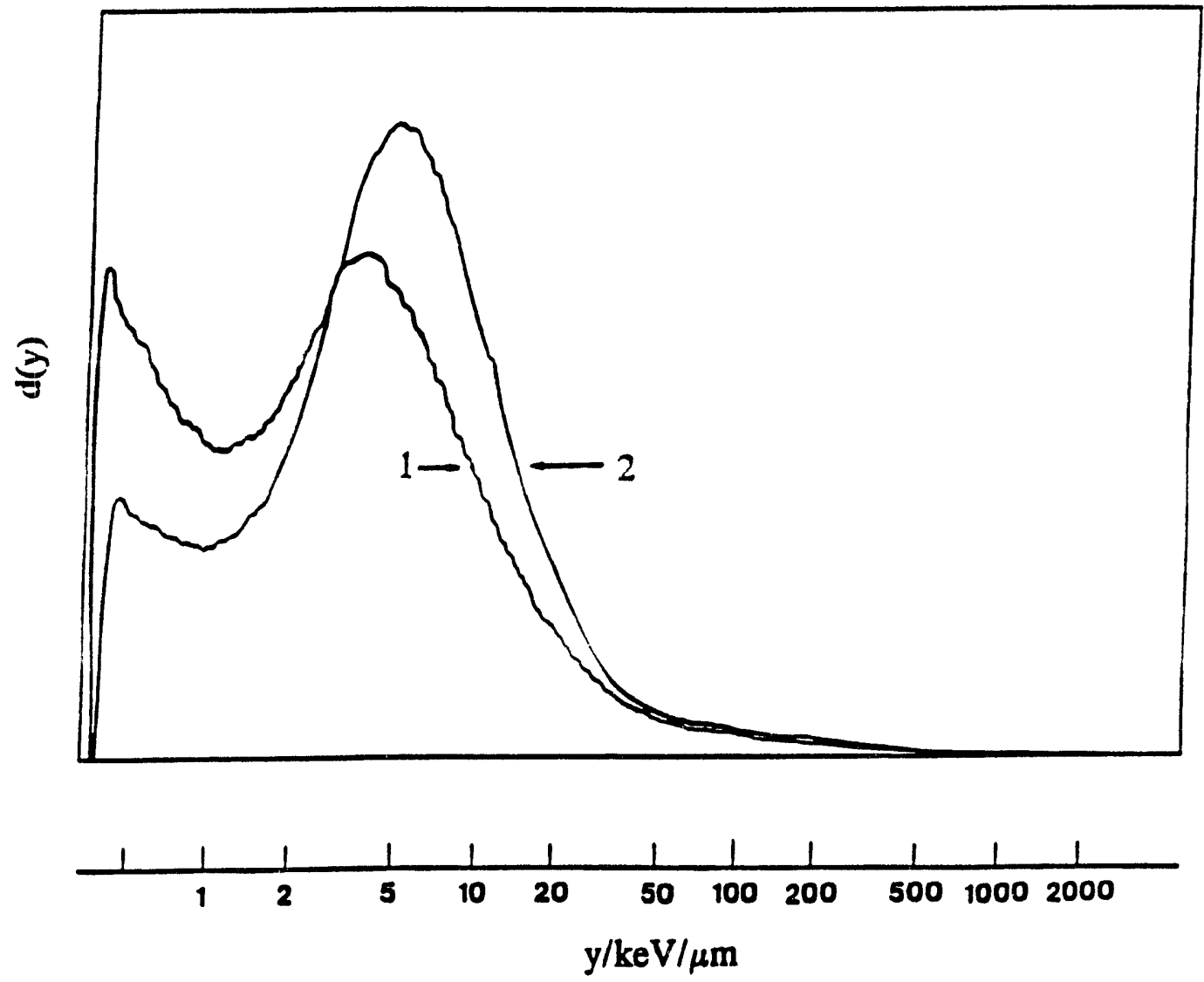

Fig.1. The influence of the inside layer thickness on the $d(y)$ vs y spectrum, $14 \mathrm{MeV}$ neutrons, 1 m site size. Wall-less spherical counter, $6.35 \mathrm{~mm}$ in diameter, Curve 1: $0.25 \mathrm{~mm}$ tissue-equivalent plastic layer, Curve 2: $3 \mathrm{~mm}$ tissueequivalent plastic layer. 
fillea with propane-based TE gas mixture (33). A constant gas pressure was maintained using a pressure and flow regulating device. Very often the measurements were performed in a closed-system mode, since no changes in energy calibration and resolution were detected over a typical period during which data were collected, lasting from $1 / 2$ to 2 hours.

\subsection{Counter calibration}

Neutron microdosimetric spectra span more than 3 decades ir energy. Therefore, it was essential to measure at least two widel $\because$ separated calibration points within these energy limits to check the linearity of the counter's response. The low energy reginn was checked with a miniature soft $\mathrm{x}$-ray tube (36) emitting $1.49-\mathrm{keV}$ Al $\mathrm{k}_{\alpha}$-line photons. For higher energies, a Einely collimated $244 \mathrm{Cm} \alpha$ source was used. For calibration, the energy deposited by $\alpha$ particles in propane TE gas was calculated using Ziegler's data (37). A third calibration source, 55Fe, was used at high gas pressures where the $5.9-\mathrm{keV}$ photons are compietely absorbed in the active volume.

our calibration measurements showed that the voltage between the counter helix and the sphere is critical in maintaining proportionality over the whole energy range (Fig. 2). The generally accepted constant-voltage ratio may lead to serious distortions at the high-energy end of the spectrum. Too low a voltage difference between the sphere and helix causes a loss of ions, whereas too high a 


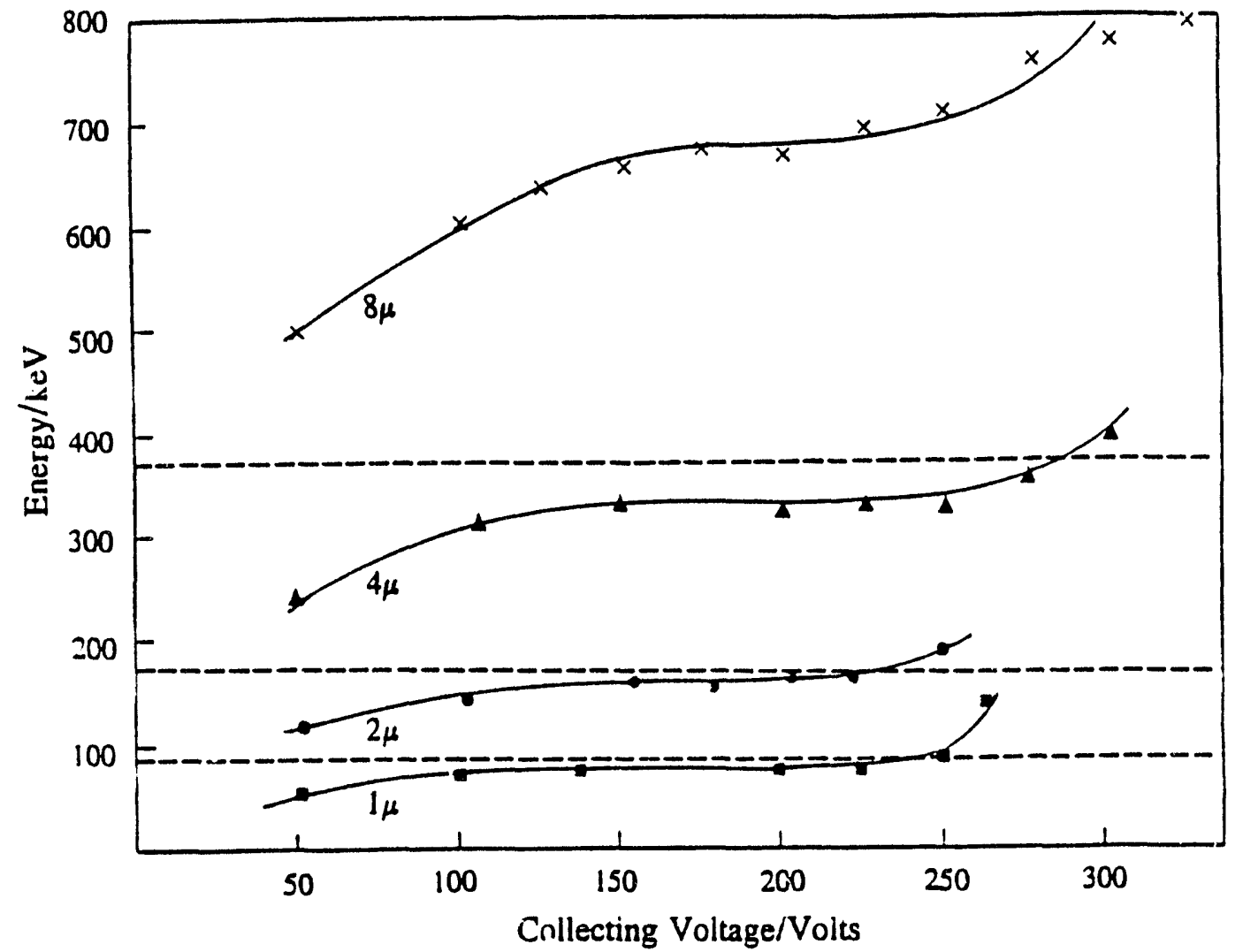

Fig. 2. Calibration of spherical proportional counter with ${ }^{244} \mathrm{Cm}$ alpha source. Horizontal scale: Collecting voltage between belix and sphere. Vercical scale: Energy deposited in the counter. Dashed horizontal lines: Calculaced values, based on Zlegler's data (37): $1 \mu-84.9 \mathrm{keV} ; 2 \mu-174.9 \mathrm{keV}$; $4 \mu-373.2 \mathrm{keV}$. The $8 \mu$ calculated value $(886.3 \mathrm{keV})$ is out of scale. The ${ }^{244} \mathrm{cn}$ calibration points are 6-78 lower in the middle of the plateau when the counter is calibraced with soft $x$-rays (Al $k_{\alpha}$-line $=1.49 \mathrm{keV}$ ) due to the difference in the corregponding $w$-values.

difference causes a nonlinear counter response. Both phenomena ars visible in the plot of charge vs collecting voltage in Fig. 2. Here, the curres correspond to saturation curves of an ionization chamber. The electric charge created by a single event in the spherical volume is toc 
small to be detected directly by electronics, hence the proportional counter inside the sphere, which multiplies the charge by a factor of $=10^{3}$. Therefore, instead of ionization current vs voltage, the graph shows the electric charge created by the calibration source after multiplication as a function of the collecting voltage, i.e. the voltage difference between the sphere and the helix. The working voltage is usually chosen in the middle of the flat plateau.

The calibration data reveal several phenomena which are imporiant, zanticulariy in high-energy neutron microcosimermy a simulated tissue sizes of $4 \mu \mathrm{m}$ and $8 \mu \mathrm{m}$. While the agreement between the calibration data is very good for the $A l x$ ray $(1.49 \mathrm{keV}$ ) and the $\alpha$ peak at small sizes $(0.25$ to $2.0 \mu \mathrm{m})$, systematic discrepancies of 10 and $25 \%$ were observel at TE gas pressures corresponding to 4 - and 8 - $\mu \mathrm{m}$ site diameters, respectively. In other words, if the 1.49 -keV calibration peak is taken as the reference point, the measured $\alpha$ peak was 10 to $25 \%$ lower than the value caiculated for these site sizes (Fig. 2). Several factors contribute to this discrepancy: a) the difference in energy per Ion pair (W-value) between the soft $x$-ray photons and the $\alpha$ particles accounts for $6-7 \%$ less ions per ionizing event for $\alpha$ particles at any gas pressure (38); b) an increasing columnar recombination at higher pressures in a densely packed heavy-ion track; and, c) an energydependent differential w-value for $\alpha$ particles. Consequently, the data for the $4-\mu \mathrm{m}$ site diameters are not as reliable as those for the the smaller site diameters. The distortion of the high energy part of the 
spectra cannot be excluded, however, it is not likely to exceed $10 \%$ on the energy scale.

\section{RESULTS AND DISCUSSION}

The most concise way to present the microdosimetric data is to tabulate mean values $\nabla_{F}$ and $\bar{\eta}_{\bar{D}}$ for the entire range of measured neutron energies and site sizes (Table 2), or to plot these values vs neutron energy, as shown for $\bar{Y}_{D}$ in Fig. 3. More complete information can be obtained from the $d(y)$ vs $\log (y)$, and $y d(y)$ vs $\log (y)$ spectra. In the latter representation, the area delimited by any two values of the Iineal energy, $y$, is equal to the fraction of dose delivered in that interval. The shape of the microdosimetric distributions, as well as changes in their shape with neutron energy or site size are fairly well understood, at least in principle $(10,15,17,19)$.

We give several examples of such spectra. Figure 4 shows the rariation of the shape of the $y d(y)$ vs log $(y)$ spectrum for $0.44-M e v$ neutrons for site sizes ranging from 1 to $8 \mu \mathrm{m}$. While the $0.25,0.5$, and i.o $\mu \mathrm{m}$ diameter spectra, (shown separately in Fig. 5, for clarity), 
TABLE 2. THE DOSE AVERAGE OF LINEAL ENERGY $\bar{Y}_{D}$ AND THE FREQUENCY MEAN OF LINEAL ENERGY $\bar{Y}_{F}$ IN REV/ $\mu$ m AS A FUNCTION OF NEUTRON ENERGY $E_{\mathfrak{n}}$ (MeV) AND SITE DIAMETER ( $\left.\mu \mathrm{m}\right)$

\begin{tabular}{|c|c|c|c|c|c|c|}
\hline$\underset{(\mathrm{MeV})}{E_{n}}$ & $\begin{array}{l}\bar{Y}_{F} \\
\bar{Y}_{D}^{\prime}\end{array}$ & 0.25 & 0.5 & $\begin{array}{l}\text { e diameter } \\
1.0\end{array}$ & $\begin{array}{r}(\mu \mathrm{m}) \\
2.0\end{array}$ & 4.0 \\
\hline \multirow{2}{*}{0.22} & $\bar{Y}_{D}$ & - & 74.5 & 69.3 & - & - \\
\hline & $\bar{Y}_{F}$ & - & 38.5 & 37.0 & - & - \\
\hline \multirow{2}{*}{0.44} & $\bar{Y}_{D}$ & 80.5 & 76.5 & 73.7 & 54.1 & 45.7 \\
\hline & $Y_{F}$ & 56.1 & 48.1 & 42.8 & 37.6 & 23.0 \\
\hline \multirow{2}{*}{1.5} & $\bar{Y}_{D}$ & 67.6 & 64.4 & 64.8 & 57.7 & 47.5 \\
\hline & $\bar{Y}_{F}$ & - & - & 44.3 & 33.8 & 32.0 \\
\hline \multirow{2}{*}{6} & $\bar{Y}_{D}$ & 60.1 & 57.5 & 57.0 & 48.3 & 37.9 \\
\hline & $\bar{Y}_{E}$ & 17.0 & 17.0 & 18.0 & 16.0 & - \\
\hline \multirow{2}{*}{14} & $\bar{Y}_{D}$ & - & 89.0 & 39.5 & - & 67.3 \\
\hline & $\bar{Y}_{F}$ & - & 9.8 & 10.1 & - & 10.1 \\
\hline
\end{tabular}

dominated by proton "crossers", are practically indistinguishable, for larger site sizes proton stoppers become increasingly important. Since a stopper deposits all its energy in the sphere, a further increase in the diameter of the sphere results only in smaller $y$-values. The spectra above $1 \mu \mathrm{m}$ shift to lower lineal values as the site size increases. This shift is accompanied by a broadening of the spectral distributions. 


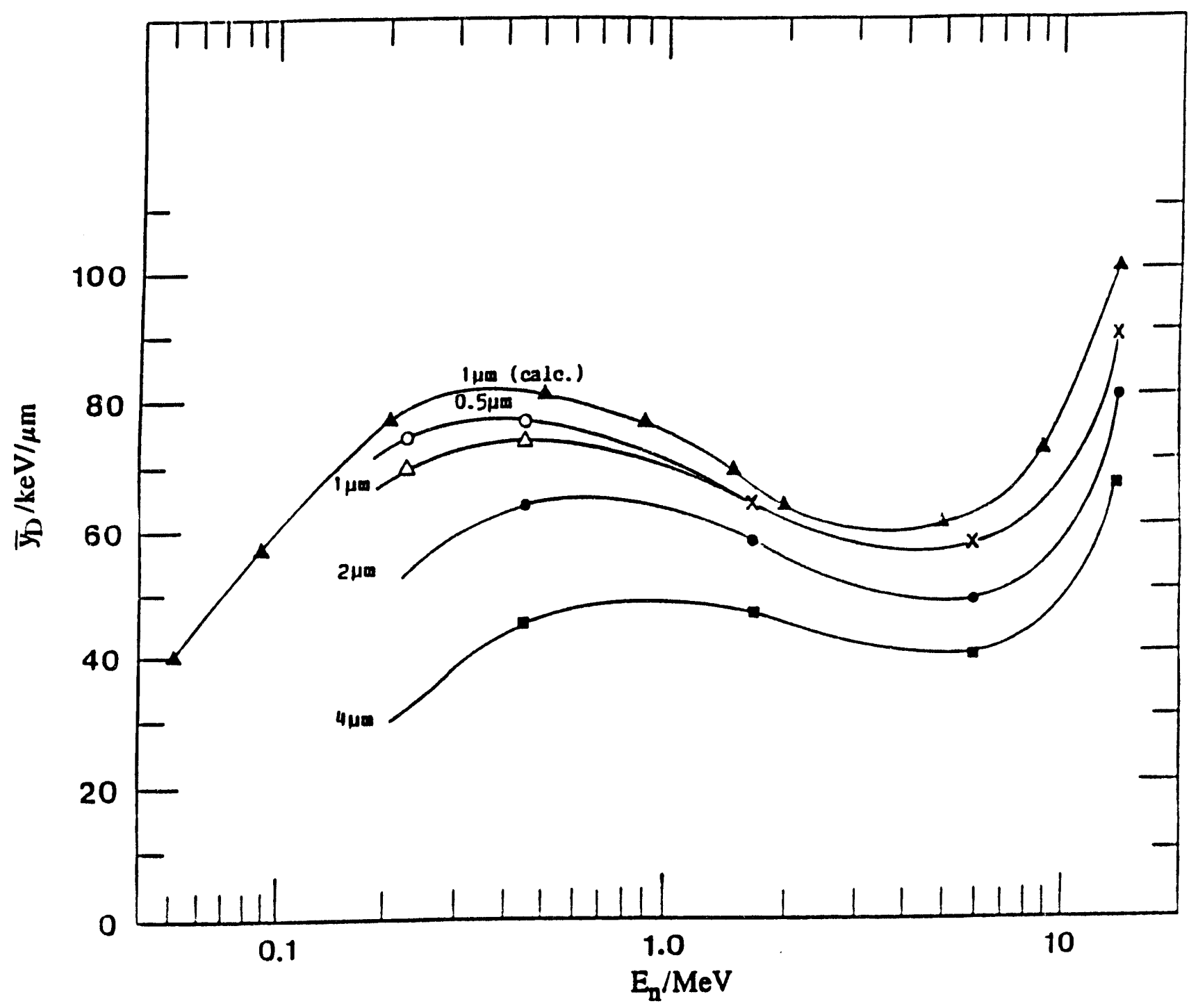

Eig. 3. The dose average of lineal energy, $\bar{Y}_{D}$, is shown as a function of neutron energy for different sizes of simulated tissue spheres. Full triangles: Calculated values $\bar{y}_{\mathrm{D}}$ for $1 \mu \mathrm{m}$ ICRU tissue sphere according to Caswell and Coyne (19). Experimental $\bar{y}_{D}$ values: Open circles, $d=0.5 \mu \mathrm{m}$. Open triangles, $d=1.0 \mu \mathrm{m}$. Experimental points for both site sizes merge at $E_{n}>1 \mathrm{MeV}$, and are denoted by $\mathrm{X}$. Full circles, $d=2 \mu \mathrm{m}$. Full squares, $d=4 \mu \mathrm{m}$. 

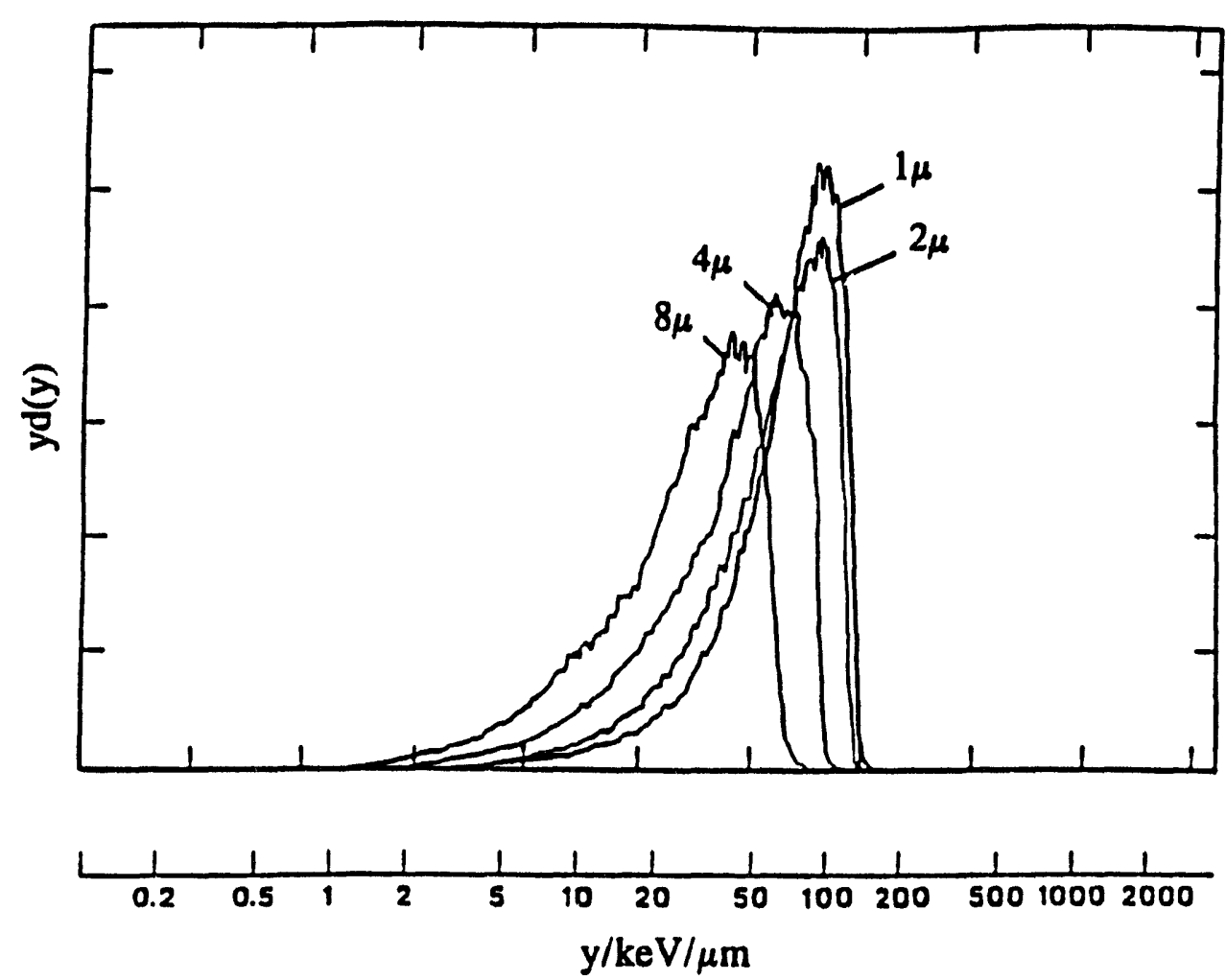

Fig. 4. yd(y) vs $\log y$ spectra, $0.44 \mathrm{MeV}$ neutrons. Variation of spectral shape a.d position with increasing site size from 1 to $8 \mu \mathrm{m}$. The $4 \mu \mathrm{m}$ and especially the $8 \mu \mathrm{m}$ site size spectra are less reliable due to calibration problems at higher gas pressure (see text).

The physical explanation is simple and straightforward. The initial proton recoil Elux, having an zpproximately rectangular spectrum, is intercepted by spheres of different dimensions. For a sphere diameter equivalent to $1 \mu \mathrm{m}$ or less of tissue, most of the recoil protons cross the sphere, producing a relatively sharp peak in the $y d(y)$ representation. As the sphere's diameter increases above $1 \mu \mathrm{m}$, an increasing fraction of recoil protons deposit their entire energy within the sphere. A further increase in diameter is not accompanied by more energy deposition, and therefore, the whole spectrum is shifted 

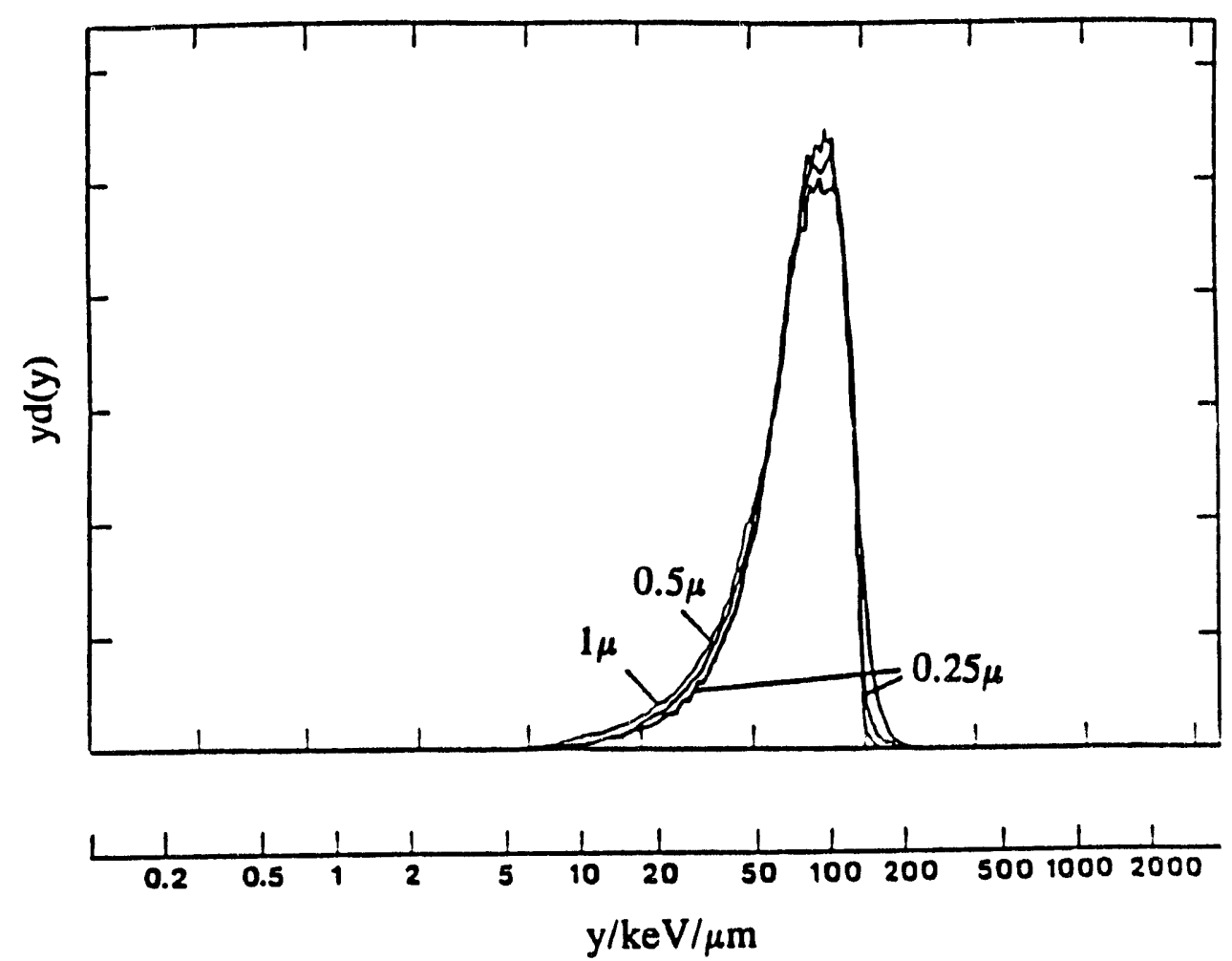

Fig. 5. yd(y) vs $\log y$ spectra, $0.44 \mathrm{MeV}$ neutrons. The shape and position of spectra representing tissue spheres of $1,0.5$, and $0.25 \mu \mathrm{m}$ in diameter do not change appreciably. Their respective mean values $Y_{D}$ change by several percent only (see Table 2).

toward lower $y$-values. The broadening of the spectrum for larger site sizes is caused by an additional term in the total variance, reflecting the shape of the initial spectrum of the recoil protons.

Figures 6 through 9 show the variation of the shape of the yd(y) vs $\log (y)$ spectrum with neutron energy and site sizes. Figures 6 and 7 show the change in spectral shape with neutron energy for a site size of $1 \mu \mathrm{m}$. The $0.22-, 0.44-$, and $1.5-\mathrm{MeV}$ spectra have a sharp proton cutoff 

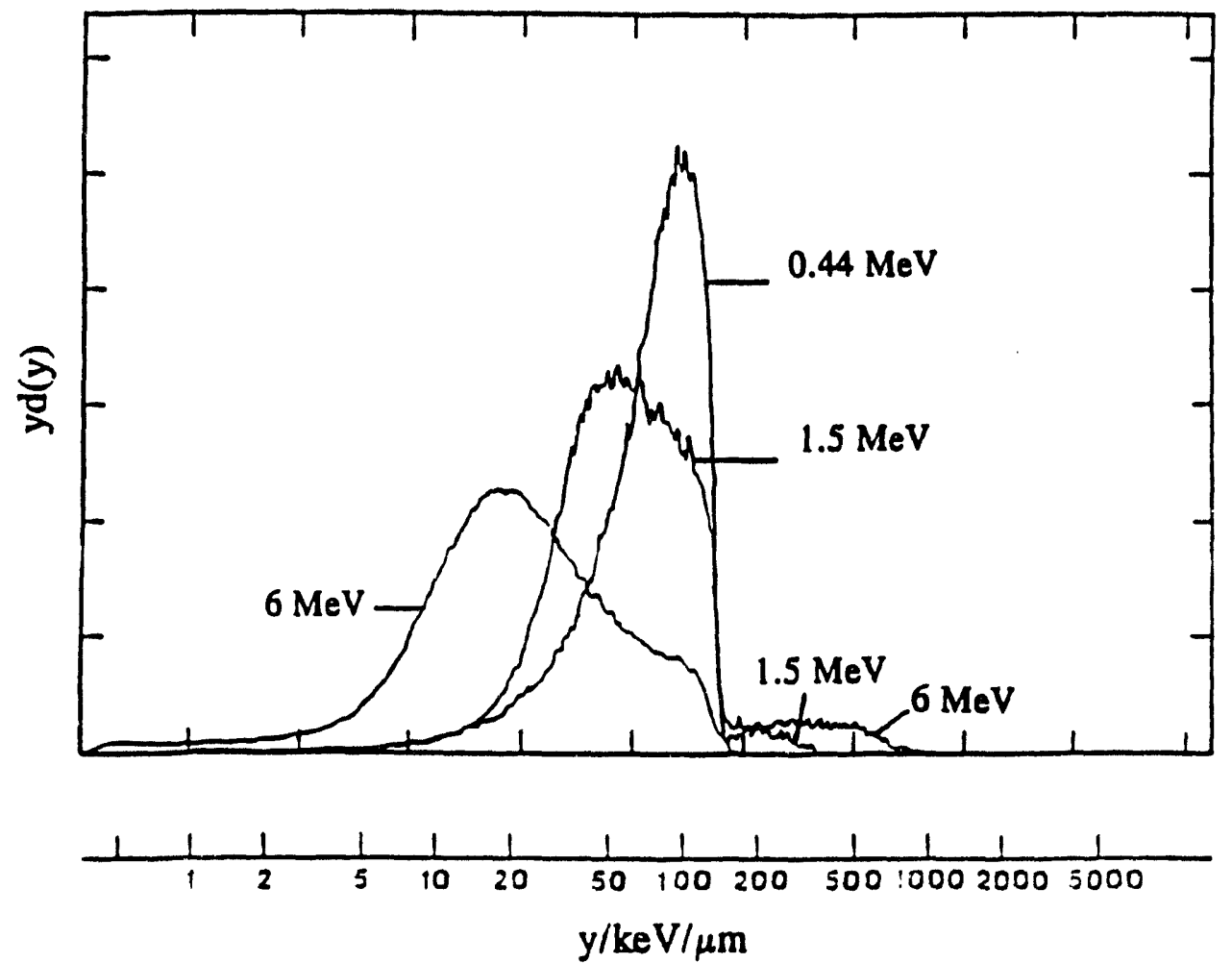

Fig. 6. Comparison of $y d(y)$ vs Iog y spectra, $1 \mu \mathrm{m}$ site size, 0.44, 1.5, and $6 \mathrm{MeV}$ neutrons. For a complete description, see Section 3.
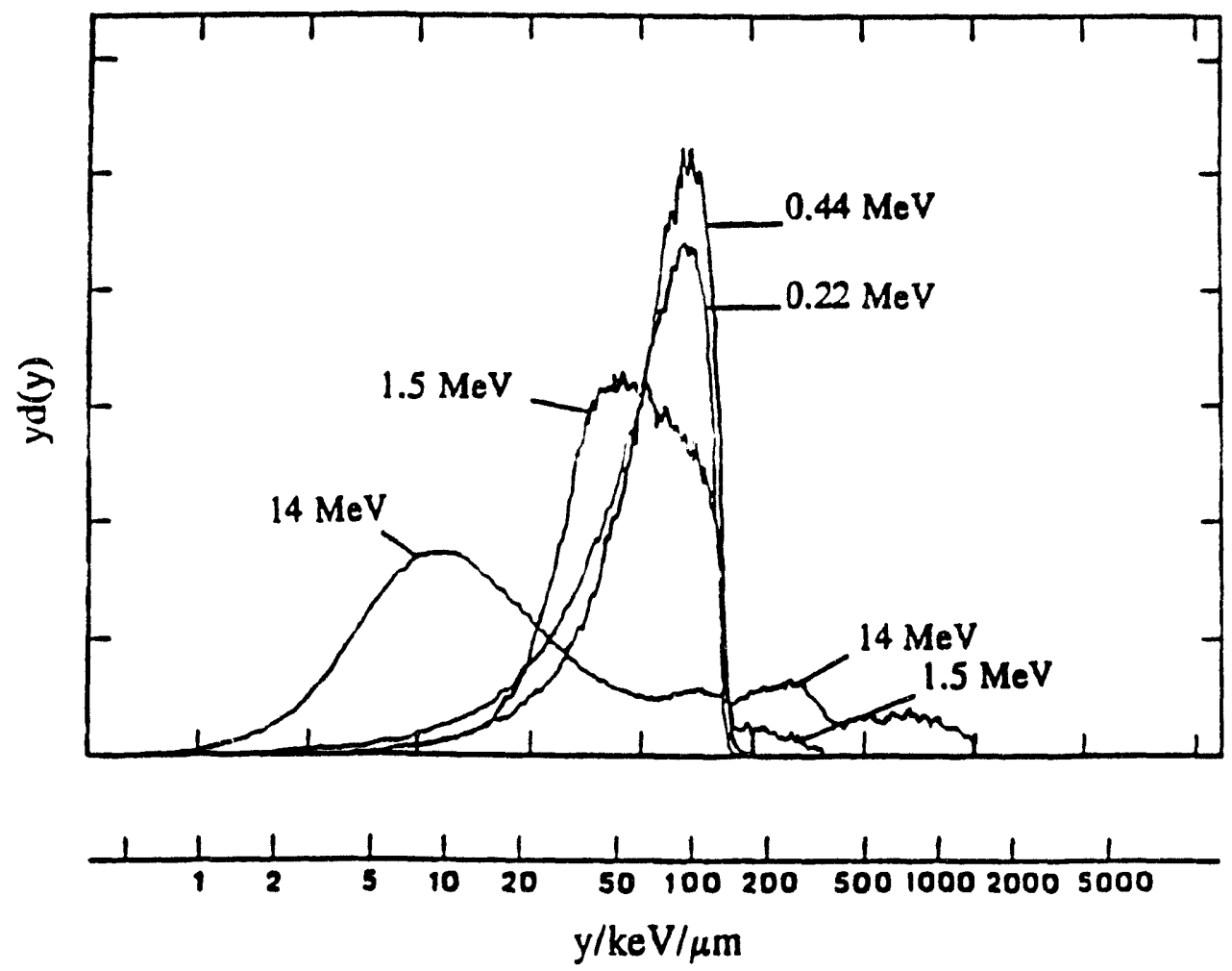

Fig. 7. Comparison of yd(y) vs log y spectra, $1 \mu \mathrm{m}$ site size, 0.22 , $0.44,1.5$, and $14 \mathrm{MeV}$ neutrons. For a complete description, see Section 3 . 


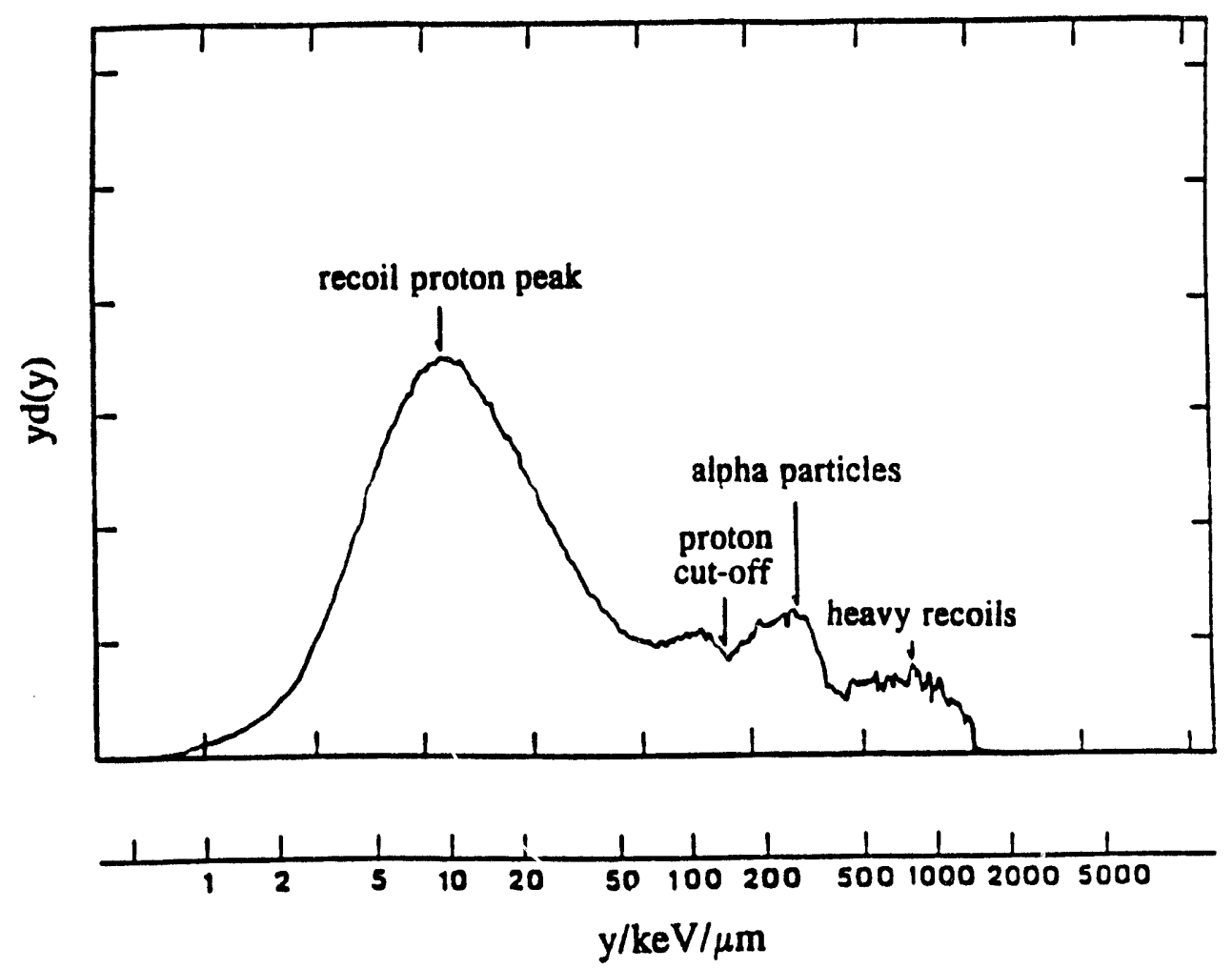

Fig. 8. yd(y) vs $\log y$ spectra, $1 \mu \mathrm{m}$ site size, $14 \mathrm{MeV}$ neutrons. Several distinct regions are marked on the spectra, indicating the contributions from protons, alpha particles, and heavy recoils to the total absorbed dose, which is proportional to the area under the curve.

at approximately $145 \mathrm{keV} / \mu \mathrm{m}$. At higher neutron energies, the recoi: proton peak is shifted to lower y-values: for $5-\mathrm{MeV}$ neutrons, the protor. peak lies around $17 \mathrm{keV} / \mu \mathrm{m}$, whereas for $14-\mathrm{MeV}$ neutrons it lies around $10 \mathrm{kev} / \mathrm{\mu m}$. Neutrons above $1 \mathrm{MeV}$ produce heavy recoils with sufEicient energy to be observed in the microdosimetric spectra. A short "tail" belonging to $\alpha$ particles and heavy recoils $(C, N$, and 0$)$ is evident between 150 and $300 \mathrm{keV} / \mu \mathrm{m}$ on the $1.5 \mathrm{MeV}$ spectrum, becoming more prominent as the neutron energy increases (see Fig. 6, 6-MeV neutrons). 


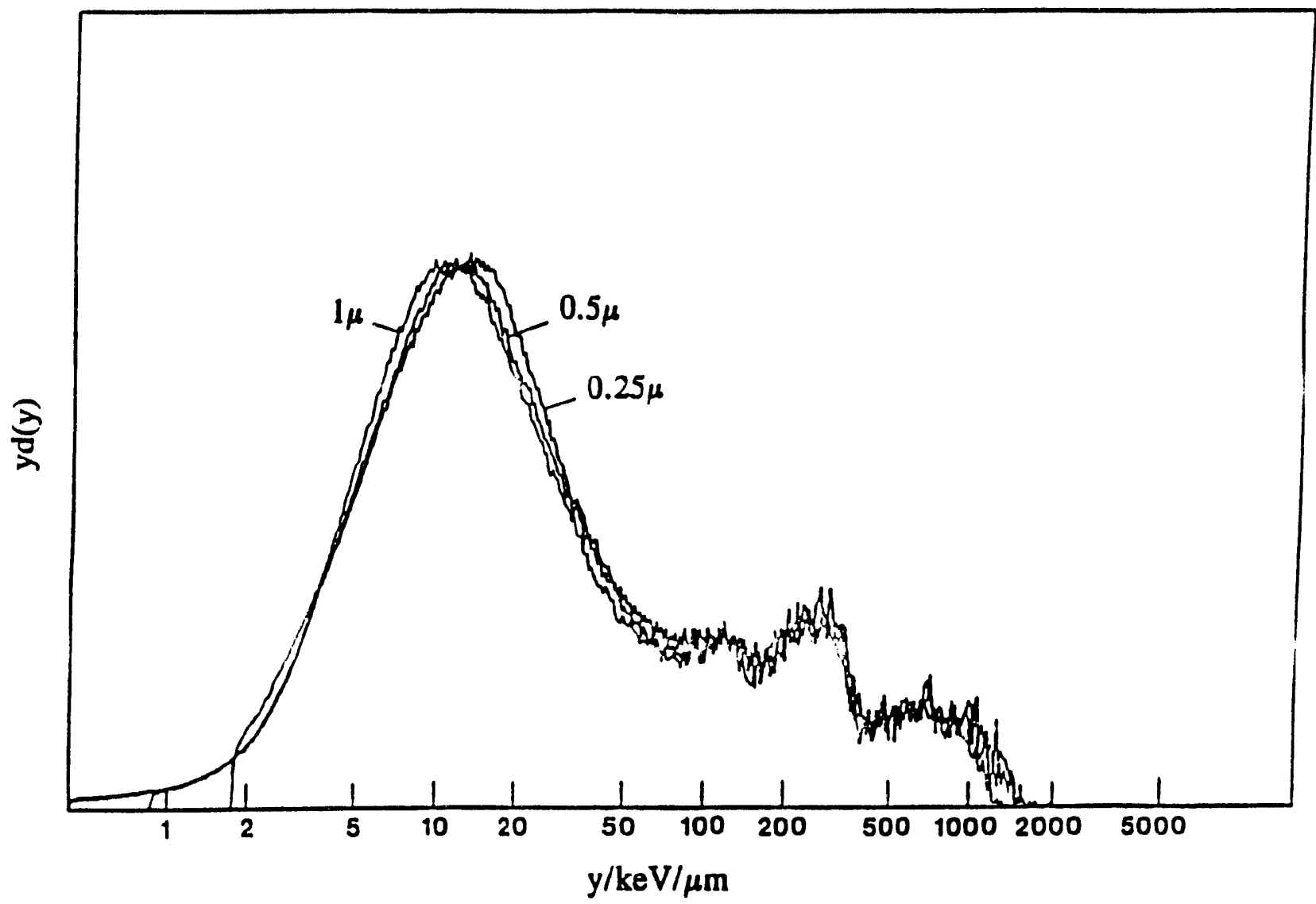

Fig. 9. $14 \mathrm{MeV}$ neutrons, $y d(y)$ vs log $y$ spectra. The shape of the spectrum for $1,0.5$, and $0.25 \mu \mathrm{m}$ spheres is practically the same.

For $14-\mathrm{MeV}$ neutrons, the high-energy tail splits into distince peaks, belonging to alphas and heavy recoils (Eig. 3). The hear: recoils, consisting mostly of carbon and oxygen ions, cannot be separated with our present technique. The variation of the shape of the yd(y) spectra with site size for $14-\mathrm{MeV}$ neutrons is shown in Fig. 9. Again, there is no significant difference between spectra for site sizes Erom 0.25 to $1 \mu \mathrm{m}$. At larger sizes, the general trend is a shift to lower values of $y$, signifying that a fraction of the heavy particles has a range comparable to $1 \mu \mathrm{m}$ in tissue. 
We attempted to calculate the frequency mean of the lineal energy, $\bar{Y}_{F}$, for several site sizes and neutron energies. In contrast to $\bar{Y}_{D}$, values of $\bar{Y}_{F}$ are very sensitive to the contribution from the lower energy part of the spectrum. To eliminate the contribution of the gammaray contamination from the neutron spectra, the subtraction procedure shown schematicaliy in Fig. 10 was applied. The d(y) vs log(y) spectra

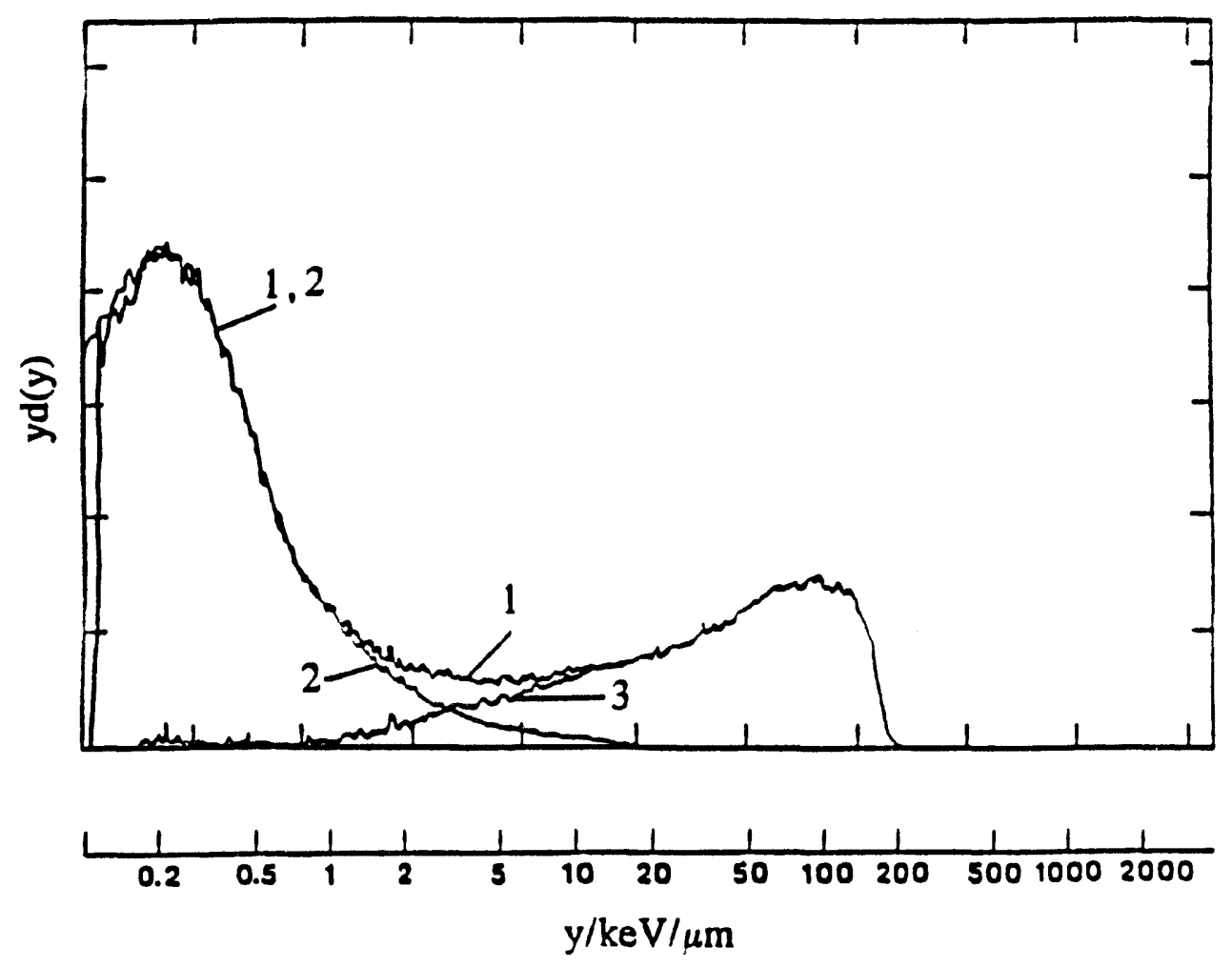

Fig.10. Processing of peurron $d(y)$ vs $\log y$ spectra, $0.22 \mathrm{MeV}$ neutrons, $1 \mathrm{~mm}$ site size. 1: Bxperimental spectrum, neutrons + gamma-rays. 2: 60 Co gamma-rays spectrum, 1 mm. 3: Net neutron spectrum, obtained by subtracting the gamma-ray spectrum from the neutron + gamma-ray spectrum. 
for $0.22 \mathrm{MeV}$ neutrons and ${ }^{60} \mathrm{Co}$ gamma rays for a $1-\mu \mathrm{m}$ site size are plotted together, matching the ${ }^{60} \mathrm{Co}$ peak to the peak at low values of $y$ in the neutron spectrum. The shapes of the overlapping sections of both spectra show that energy deposition below $1 \mathrm{keV} / \mu \mathrm{m}$ is almost entirely due to gamma rays. The region between 1 and $10 \mathrm{keV} / \mu \mathrm{m}$ consists of a mixture uf a high lineal energy tail of gamma-ray depositions and a low lineal energy tail of short or truncated proton tracks within the sphere. Above $10 \mathrm{keV} / \mu \mathrm{m}$, the spectrum is composed entirely of recoil protons. We note that the spectrum of gamma-ray energy depositions which contaminates the neutron beam is not identical to a 60 Co gamma-ray spectrum. However, the difference in the shape of the mizrodosimetric spectra for gamma rays having a wide range of energies, e.g., ${ }^{137} \mathrm{Cs}$ $(E=0.66 \mathrm{MeV}), \quad{ }^{60} \mathrm{Co}\left(E_{1}=1.2 \mathrm{MeV}, \quad E_{2}=1.33 \mathrm{MeV}\right), \quad$ and ${ }^{24} \mathrm{Na}(E=2.76 \mathrm{MeV})$, is small, thus justifying the subsequent step of subtracting the ${ }^{60} \mathrm{Co}$ gamma-ray spectrum, leaving the residual spectrum which represents the net neutron energy depositions. The mean value $\bar{Y}_{F}$ changes drastically after subtracting the gamma-ray contamination, however, no significant change in the values of $\bar{y}_{D}$ was observed after subtracting the jamma zomponent. For instance, in case or 0.22-igy neutrons, the $\bar{Y}_{F}$-value increased from $12.2 \mathrm{keV} / \mu \mathrm{m}$ to $37.0 \mathrm{keV} / \mu \mathrm{m}$, while the $\bar{y}_{D}$-value changed fram $63.9 \mathrm{keV} / \mu \mathrm{m}$ to $69.3 \mathrm{keV} / \mu \mathrm{m}$. The difference in $\bar{Y}_{D}$-values before and after subtraction of the gamma-ray contamination decreases as neutron energy increases.

Table 2 gives the values of $\bar{Y}_{F}$ obtained after the gamma-ray subtraction. Booz (39) recommended various procedures to extrapolate 
events below $y=0.05 \mathrm{keV} / \mu \mathrm{m}$, which are usually overlapped by electronic noise. The values obtained were found to change by only a few percent when the "pure" neutron spectra were further extrapolated exponentially to zero lineal energy. Consequently, the $\bar{Y}_{F}$-values of Table 2 were calculated with no extrapolation. Table 3 compares three sets of experimental data for $14 \mathrm{MeV}$ neutrons. Our data agree fairly well with those of Rodgers and Gross (6). The values of $\bar{y}_{D}$ first reported by Biavati and Boer were calculated assuming the LET for $244 \mathrm{Cm} \alpha$ particles used for calibration was $77.8 \mathrm{keV} / \mu \mathrm{m}$. In their data from 1955 on, $=2$. LET was recalculated as $87.7 \mathrm{keV} / \mu \mathrm{m}$, using new stopping power data. Therefore, we applied a correction to the older data Jf Biavati and Boer. First, the old notation was converted into present notation by multiplying the $\bar{y}_{D}$ values by $3 / 2$; then, a correction factor of 1.127 was used to correct the $\alpha$-particle calibration. Remarkably, our data, the Rodgers and Gross data (6), and the LET-corrected early data of Biavar: and Boer (1), for $14 \mathrm{MeV}$ neutrons and $1 \mu \mathrm{m}$ site are in surprisingly good agreement, giving an average value $\bar{y}_{D}=89.5 \mathrm{keV} / \mu \mathrm{m}$, and less than $a 1 \frac{2}{3}$ departure of each individual measurement from the mean value. However, Eor other site sizes, as weil as the later data of Biavati and Boer, :i, the agreement is not nearly as good. The calculated $\bar{Y}_{D}$ values of Caswell and Coyne (19) for ICRU tissue are generally higher than the 
TABLE 3. COMPARISON OF EXPERIMENTAL DATA FOR $14 \mathrm{MeV}$ NEUTRONS: $\bar{Y}_{D}$ IN $\mathrm{keV} / \mu \mathrm{m}$ FOR VARIOUS SPHERE DIAMETERS

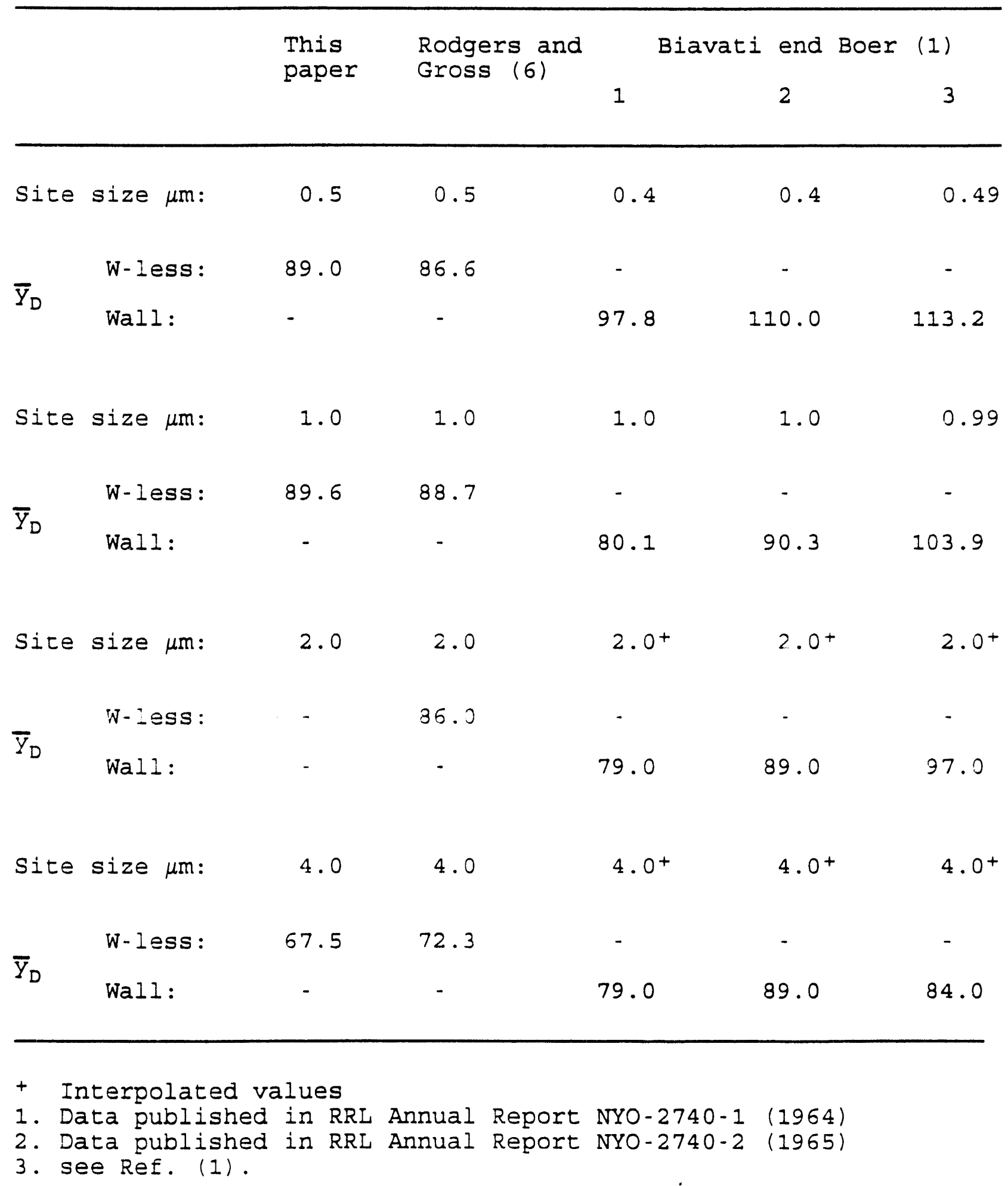


experimental data by 10 to $25 \%$ (see Fig. 3). However, it should be pointed out that 3 out of 4 experimental sets of data (including the early Biavati and Boer data) have consistently lower $\bar{Y}_{D}$ values than the calculated ones. The discrepancy can be explained at least qualitatively as follows: a) the experimental values need correction for the different values of $W$, as discussed; b) more precise and complete input data for the calculations are required, as pointed out by Caswell and Coyne (19); and, c) the calculations are for ICRU tissue, not for methane- or propane-based $T E$ gas and $T E$ plastic. While the $W$ correction inizl definitely help to bring the experimental and the calculated data closer, the effect of the remaining two changes is unknown.

The ultimate use of the microdosimetric data presented in Figs $3-9$ or the mean values $\bar{Y}_{F}$ and $\bar{Y}_{D}$ must be born in mind. For radiobiological purposes, the uncorrected values may be more relevant since the irradiated samples will absorb both the gamma-rays and the neutron-induced radiation (recoil protons and heavy ions). On the other hand, for comparison with calculated values of $\bar{Y}_{F}$ and $\bar{Y}_{D}$, as well as for radiation physics, it is better to nave a ciear-cut picture oI che contribution of each type of radiation to the total absorbed dose and their respective microdosimetric spectra. 


\section{ACKNOWLEDGMENTS}

The authors would like to acknowledge Leon J. Goodman, Marco Zaider and Robert E. Mills for their assistance in making the measurements of the spectra and Harald H. Rossi for initiating and promoting this research. 


\section{REFERENCES}

1. M.H. BIAVATI and E. BOER, Monoenergetic neutrons. U.S. Atomic Energy Commission Report NYO-2740-4, 74-80, (1967).

2. U. OLDENBURG and J. BOOZ, Calculation and measurement of neutron-produced single-event spectra. Radiat. Res. 51, 551-558 (1972).

3. R. RODGERS, J.F. DICELLO, and W. GROSS, Event distribution from monoenergetic neutrons. U.S. Atomic Energy Commission Report COO-3243-2, 87-101 (1973).

4. J. BOOZ and M. COPPOLA, Energy deposition by fast neutrons to small spheres. In Proc. of the Fourth Symposium on Microdosimetry (J. BOOZ, H.G. EBERT, R. EICKEL and A. WAKER, Eds), EURATOM DOC EUR 5122, 983-998 (1974).

5. M. COPPOLA, D. PIRRWITZ, and J. BOOZ, Influence of detector size and thickness on neutron produced energy deposition spectra. In Proc. of the Fourth Symposium on Microdosimetry (J. BOOZ, H.G. EBERT, R. EICKEL and A. WAKER, Eds), EURATOM DOC EUR 5122, 1001-1013 (1974).

6. R. RODGERS and W. GROSS, Microdosimetry of monoenergetic neutrons. In Proc. of the Fourth Symposium on Microdosimetry, (J. BOOZ, H.G. EBERT, R. EICKEL and A. WAKER, Eds), EURATOM DOC EUR 5122 d-e-f, 1027-1042 (1974).

7. D. SRDOĆ, L.J. GOODMAN, S.A. MARINO, R.E. MILLS, M. ZAIDER, and H.H. ROSSI, Microdosimetry of monoenergetic neutron radiation. In Proc. of the Seventh Symposium on Microdosimetry, EURATOM DOC EUR 7147, DE-EN-FR, 765-774 (1981). 
8. P. COLAUTTI, M. CUTAIA, M. MAKAREWICZ, H. SCHRAUBE, G. TALPO, and G. TORNIELLI, Neutron microdosimetry in simulated volumes less than $1 \mu \mathrm{m}$ in diameter. Radiat. Prot. Dosim. 13, 117-121 (1985).

9. P. KLIAUGA, J. HORTON, and P. STAFFORD, Microdosimetry of a $42 \mathrm{MeV}$ therapy neutron beam. Int. $J$. Radiat. Oncol. Biol. Phys. $16(3), 845-848(1989)$.

10. R.S. CASWELL, Deposition of energy by neutrons in spherical cavities. Radiat. Res. 27,92-107 (1966).

11. R.I. BACH and R.S. CASWELL, Energy transfer to mateer by neutrons. Radiat. Res. 35, 1-25 (1968).

12. R.F. DVORAK, Calculation of $\mathrm{dE} / \mathrm{dx}$ and energy loss distributions in spherical cavities for monoenergetic neutron fields. Health Phys. 17, 279- (1969).

13. R.S. CASWELL and J.J. COYNE, Interaction of neutrons and secondary charged particles with tissue: secondary particle spectra. Radiat. Res. 52, 448-470 (1972).

14. U. OLDENBURG and $\mathrm{J}$. BOOZ, Mass stopping power and pathlength of neutron produced recoils in tissue and tissue equivalent materials, I. Neutron energy $6 \mathrm{MeV}$. EURATOM DOC EUR $4786 \mathrm{e}$ $(2972)$.

15. R.S. CASWELL and J.J. COYNE, Neutron energy deposition spectra studies. In Proc. of the Fourth Symposium on Microdosimetry (J. BOOZ, H.G. EBERT, R. EICKEL and A. WAKER, Eds), EURATOM DOC EUR 5122 d-e-f, 967-982 (1974).

16. A.A. EDWARDS and J.A. DENNIS, The calculation of charged particle fluence and LET spectra for the irradiation of biologically significant materials by neutrons. Phys. Med. Biol. 20, 395-409 (1975). 
17. R.S. CASWELL and J.J. COYNE, Microdosimetric spectra and parameters of fast neutrons. In Proc. of the Fifth Symposium on Microdosimetry EURATOM DOC EUR 5452 d-e-f, 97-126 (1976).

18. M. COPPOLA and J. BOOZ, Neutron scattering and energy deposition spectra. Radiat. Environ. Biophys. 12, 157-168 (1975).

19. R.S. CASWELI and J.J. COYNE, Energy deposition spectra for neutron based on recent cross section evaluations. In Proc. of the Sixth Symposium on Microdosimetry ( $\mathrm{J} . \mathrm{BOOZ}$, and H.G. EBERT, Eds), Brussels, 1159-1171 (1978).

20. R.S. CASWELL and J.J. COYNE, EfEects of track structure on neutron microdosimetry and nanodosimetry. Nucl. Tracks Radiat. Meas. 16, 187-195 (1989).

21. A.M. KELLERER, Microdosimetric data and the biological effectiveness of neutrons. In Proc. of the second Symposium on Neutron Dosimetry in Biology and Medicine (G. BURGER and H.G. EBERT, Eds) EURATOM DOC EUR 5273 d-e-f, 71-91 (1975).

22. Proc. IAEA Advisory Group Meeting on Nuclear and Atomic Data for Radiotherapy and Radiobiology, Rijswijk, 1985. STI/PUB/741, (Vienna: IAEA) (1987).

23. A. WAMBERSIE, J. VAN DAM, G. HANKS, B.J. MIJNHEER, and J.J. BATTERMAN, Need for improving the accuracy in dose delivery in radio- and neutron therapy: Importance of atomic and molecular data. In IAEA-TECDOC 506 (1989) 51-72.

24. H.M. GERSTENBERG, R.S. CASWELL, and J.J. COYNE, Initial spectra of neutron-induced secondary charged particles. Radiat. Prot. Dos. 23, 41-44 (1988). 
25. INTERNATIONAL COMMISSION ON RADIATION UNITS AND MEASUREMENTS. The Quality Factor in Radiation Protection, ICRU Report No. 40, 1986.

26. J.W. BAUM, A.V. KUEHNER and R.L. CHASE, Dose equivalent meter design based on tissue equivalent proportional counters. Health Phys., Vol. 19, 813-824 (1970).

27. G. DIETZE, S. GULDBAKKE, H. KLUGE and $T$. SCHMITZ, Intercomparison of radiation protection instruments based on microdosimetric principles. Phys.-Tech. Bundesanstalt, Braunschweig, Germany, Report No. PTB-ND-29, 46 pp (1986).

29. I.A.M. AL-AFEAN, A new concept in microdosimetry to evaluate the quality factor for neutrons and photons. Rad. Prot. Dos., $23(1-4), 83-86(1988)$.

29. D. SRDOČ, R.E. MILLS and S.A. MARINO, Microdosimetry measurements at the RARAF. Progress Report, Columbia University, COO-4733-2, 95-101 (1979).

30. D. SRDOČ, L.J. GOODMAN, S.A. MARINO and M. ZAIDER, Neutron Microdosimetry at RARAF. Progress Report, Columbia University, COO-4733-3,42-60 (1980).

31. INTERNATIONAL COMMISSION ON RADIATION UNITS AND MEASUREMENTS, ICRU Report NO. 10B, 1964.

32. INTERNATIONAL COMMISSION ON RADIOLOGICAL UNITS AND MEASUREMENTS, ICRU. Radiation Quantities and Units, Report No. 19, Washington, D.C. 1971.

33. D. SRDOČ, Experimental technique of measurement of microscopic energy distribution in irradiated matter using Rossi Counters. Radiat. Res. 43, 302-319 (1970). 
34. V. RADEKA, Low-noise techniques in detectors. Ann. Rev. Nucl. Part. Sci. 38, 217-277 (1988).

35. V. RADEKA, Logarithmic charge amplifier for scintillation detectors. Nucl. Instr. Meth. 113, 401 (1973).

36. D. SRDOC and B.C. CLARK, Generation and spectroscopy of ultrasoft $x$-rays by non-dispersive methods. Nucl. Instr. Meth. 78, $305-313(1970)$.

37. J.F. ZIEGLER, Helium Stopping Powers and Ranges in All Elements. Vol. 4. Pergamon Press, New York (1977).

38. D. SRDOĆ, M. INOKUTI, I. KRAJCAR-BRONIĆ, E. WAIBEL, Y. HATANO and I. KAPLAN, Yields of ionization and excitation in irradiated matter. BNL Report-48079, 94 pp (1992).

39. J. BOOZ, Microdosimetric data and parameters of low LET radiations. In Proc. of the Fifth Symposium on Microdosimetry, EURATOM DOC EUR 5452 d-e-f, 311-245 (1975). 

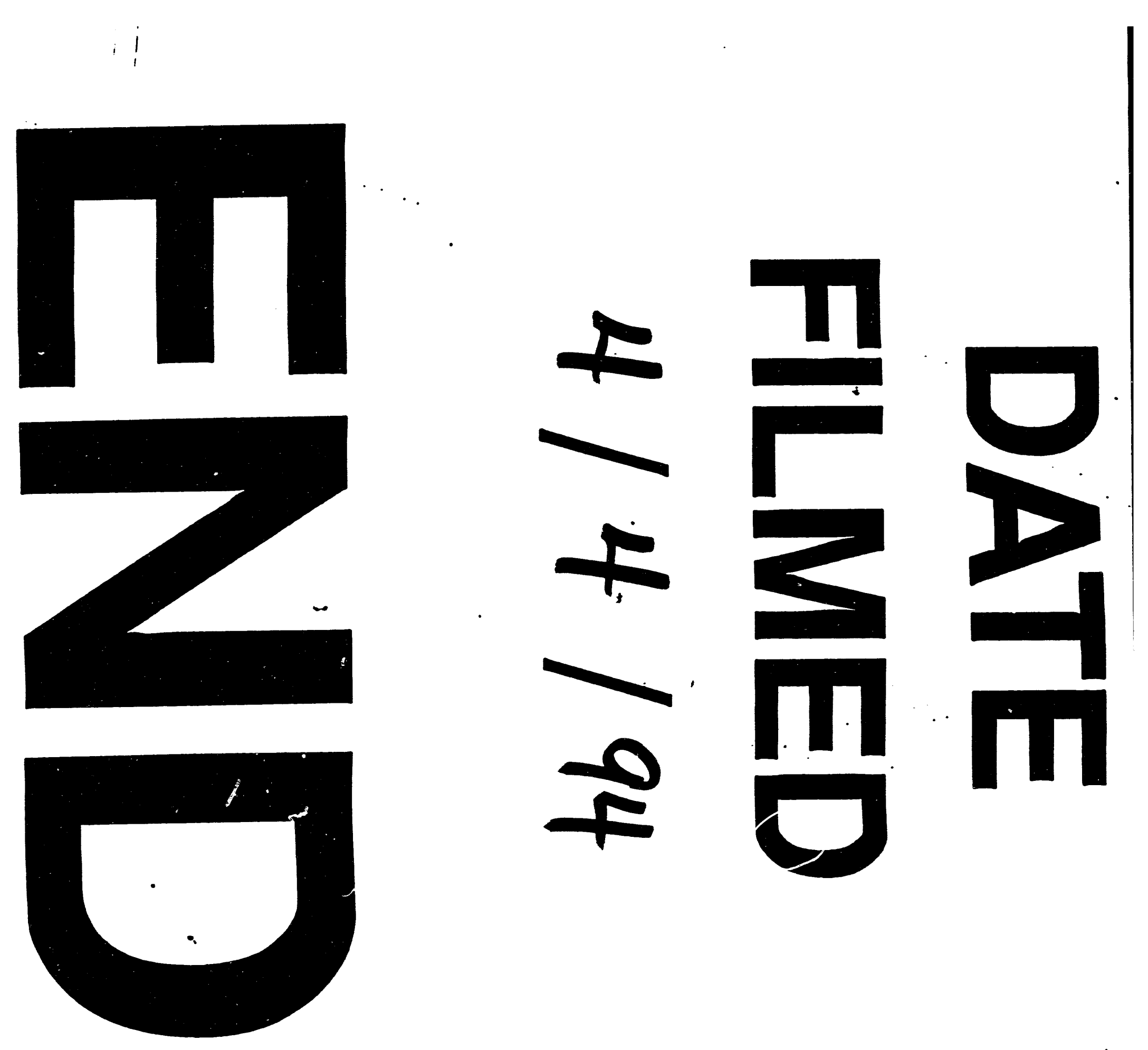
